\title{
Predicting urban forest growth and its impact on residential landscape water demand in a semiarid urban environment
}

\author{
John H. Lowry Jr. ${ }^{\mathrm{a}, *}$, R. Douglas Ramsey ${ }^{\mathrm{b}}$, Roger K. Kjelgren ${ }^{\mathrm{c}}$ \\ a Department of Environment and Society, UMC 5215, Utah State University, Logan, UT 84322-5215, United States \\ b Department of Wildland Resources, UMC 5230, Utah State University, Logan, UT 84322-5230, United States \\ ' Department of Plants, Soils and Climate, UMC 4820, Utah State University, Logan, UT 84322-4820, United States
}

\section{A R T I C L E I N F O}

Keywords:

Geographic information systems

Irrigation water demand

Residential landscapes

Urban forestry

Urban tree canopy

\begin{abstract}
A B S T R A C T
We present an innovative approach to estimating residential irrigation water demand for a large metropolitan area using GIS data, weather station data, and a water budget modeling approach commonly used by plant scientists and landscape management professionals. An important question addressed by our study is how a growing urban forest affects the overall irrigation water demand of a semiarid metropolitan area. To estimate the amount of water required by residential landscaping, we consider water demand to be a function of the areal extent of residential landscaping (i.e. tree/shrub or turf grass), the water-loss rate for different landscaping types, the efficiency with which the landscape is irrigated, and local climatic factors (i.e. reference evapotranspiration and precipitation). We estimated irrigation water demand for 542 residential neighborhoods in Salt Lake County, UT, USA for 2005. To investigate the effects of a maturing urban forest on water demand, we used simultaneous autoregression (SAR) models to predict the spatial extent of future forest canopy and future exposed turf grass in residential neighborhoods. For both the forest canopy model and the turf grass model we used the median age of housing stock as the dependent variable. Psuedo $R^{2}$ were 0.70 and 0.82 for the tree/shrub canopy and turf grass models, respectively. Based on projected areal extents of tree/shrub canopy, exposed turf grass, and turf grass under canopy, we estimated future water demands for the 542 residential neighborhoods. Our predictive model suggests that as urban tree canopy increases in residential urban areas, exposed turf grass decreases, with a net effect of a slight decrease in residential landscape water demand. This can be explained by the relative differences in water lost through evapotranspiration by different landscape types, namely; trees/shrub (i.e. woody plants), exposed turf grass, and turf grass under tree canopy.
\end{abstract}

(c) 2011 Elsevier GmbH. All rights reserved.

\section{Introduction}

The importance of trees in urban areas has been recognized for millennia (Miller, 1997). However in a rapidly urbanizing world, potential environmental and economic benefits offered by urban forests are increasingly important factors influencing urban planning and policy (Heynen and Lindsey, 2003; Conway and Urbani, 2007). Potential benefits include reduced energy consumption (Huang et al., 1990; McPherson, 1990), storm water control (McPherson, 1992; Xiao et al., 1998), habitat for increased biodiversity (Johnson, 1988), improved air quality (Nowak et al., 2006), and carbon storage and sequestration (Nowak and Crane, 2002).

\footnotetext{
* Corresponding author. Current address: School of Geography, Earth Sciences \& Environment, University of the South Pacific, Private Mail Bag, Laucala Campus, Suva, Fiji Islands. Tel.: +679 323 2549; fax: +679 3231509.

E-mail addresses: lowry_j@usp.ac.fj (J.H. Lowry Jr.), doug.ramsey@usu.edu (R.D. Ramsey), roger.kjelgren@usu.edu (R.K. Kjelgren).
}

Based on growing evidence that urban trees provide numerous benefits, cities in the U.S. and around the world are mounting campaigns to cultivate more urban trees (Brown, 2008; McPherson et al., 2008). Few have questioned the benefits of the urban forest, and in benefit-cost analyses the costs associated with urban forests have focused primarily on maintenance, planting, removal, and damage caused by roots and limbs (Nowak and Dwyer, 2007).

An important challenge associated with urbanization in the $21 \mathrm{st}$ century is an increasing demand for water (Gleick, 2000). Population growth and the specter of a changing climate make the question of urban water demand particularly critical (Vorosmarty et al., 2000). Urban landscaping in cities in the western U.S. can consume up to $50 \%$ of the municipal water budget (Vickers, 1991; Bishop and Hughes, 1993; Hanak and Davis, 2006). As various campaigns promoting the benefits of urban trees continue, a better understanding of how a growing urban forest impacts residential irrigation water demand is critical to the design and management of sustainable cities. 


\section{Urban forest growth}

A common measure of urban forest growth is the amount of leaf area provided by urban trees, and is typically measured as the percentage of an area that is covered (from a plan view) by tree canopy (Sanders, 1984). Within the last decade, considerable research has focused on how forests grow across an urban landscape, and specifically how certain factors account for spatial differentiation in urban tree canopy cover. Household income for example has been shown to be positively correlated with higher tree canopy (Iverson and Cook, 2000; Grove et al., 2006; Troy et al., 2007) and there is evidence that education (Heynen and Lindsey, 2003; Troy et al., 2007) and family life-stage (Lowry, 2010) are also correlated to tree canopy abundance. While there is some evidence that topographic gradients such as aspect and elevation, are correlated with urban tree canopy abundance, it is most likely that limitations of resources such as water and nutrients in an urban setting are controlled more by landscape management than by natural processes (Hope et al., 2003). The role of humans in urban areas accounts for much of the variation observed in the urban tree canopy.

An additional factor influencing forest growth in urban areas that receives less attention - perhaps because of its obvious role - is the amount of time that has passed since the land was developed. Lowry (2010) demonstrated that among several social and physical landscape factors, the age of a residential neighborhood was the most influential factor explaining tree canopy abundance. The importance of neighborhood age has been noted by others. In Phoenix, AZ, USA Hope et al. (2003) and Martin et al. (2004) found that the abundance and diversity of urban vegetation decreases with neighborhood age, while in Baltimore, MD Grove et al. (2006) and Troy et al. (2007) found the abundance of neighborhood tree canopy increases with housing stock age to a point at about 45 or 50 years, whereupon it decreases as neighborhoods get older. Troy et al. (2007) suggest the parabolic nature (inverted $U$ ) of the urban tree canopy-to-neighborhood age relationship may reflect changes in past planting efforts. Maco and McPherson (2002) suggest that the inverted $U$ relationship between tree canopy and time reflects a natural climax of the first generation urban forest stand. As mature trees die off and are not replaced, tree canopy abundance of the first generation stand reaches a maximum cover at around 50\%, then decreases, stabilizing at around 30\% cover. Maco and McPherson (2002) were primarily concerned with canopy of urban street trees, but it is reasonable to extend their explanation of urban forest cover in relation to time to include residential forest stands.

\section{Urban water demand}

Methods for forecasting urban water demand have been extensively studied in civil and environmental engineering, econometrics, and other related fields (Baumann et al., 1998). The simplest models estimate current demand as a function of per capita water-use multiplied by total urban population. Future demand is forecast by extrapolating current demand to projected populations based on an accepted population growth rate (Baumann et al., 1998). In a more elaborate example, Lee et al. (2010) used projected population density to spatially predict future municipal water demand with a Bayesian Maximum Entropy model. Models incorporating additional explanatory variables such as land use, per capita income, housing size, water costs, and climatic factors have also been developed (Jain et al., 2001; Arbues et al., 2003). Methodological approaches include empirically based models using a variety of regression techniques (Jain et al., 2001; Arbues et al., 2003), mechanistic models (Dziegielewski and Boland, 1989), and artificial neural networks (ANN) (Jain et al., 2001; Msiza et al., 2008).
Urban water requirements are typically divided into municipal and industrial water uses, with municipal water including both residential and commercial allotments (Baumann et al., 1998). Residential water consumption can be divided into indoor and outdoor uses but estimates of residential demand typically do not distinguish the two (Arbues et al., 2003), probably because water supply companies rarely account for these two uses separately (UDNR-DWR, 2009). Outdoor water uses vary dramatically depending on income and geography. Landscaping and swimming pools, for example, account for a large portion of residential outdoor water use in Phoenix, AZ (Wentz and Gober, 2007). Residential landscaping is one of the most promising segments of the urban water budget for conservation (Farag, 2003), though there have been few assessments of water demand for residential landscape uses at the city or municipal level (Farag, 2003; Endter-Wada et al., 2008).

\section{Water needs for residential landscapes}

To assess water requirements for residential and commercial landscapes, plant and horticultural scientists have adopted methods originally developed in agronomy to quantify the amount of water lost through evapotranspiration by different plant types (Kjelgren et al., 2000). Reference evapotranspiration (ETo) is a hypothetical water-loss rate adopted by the United Nations Food and Agriculture Organization (UNFAO) as a standard measure by which other crops can be compared (Allen et al., 1998), and is calculated using meteorological data, making it possible to determine water requirements for given plants in different climatic regions. Using this approach, the evapotranspiration rate of a plant is expressed as a proportion of ETo. The proportion of ETo required by a plant to thrive productively is referred to as the water-loss crop coefficient $(K c)$. Thus, the $K c$ for a given crop may be 0.60 meaning it requires $60 \%$ of ETo for maximum growth and production. Applying the concept of ETo and crop coefficients to landscape plants is relatively new, and with the exception of turf grasses (Kneebone et al., 1992), few coefficients have been derived for specific landscape plants. It is nevertheless widely used by plant scientists and landscape management professionals to assess water needs of urban/suburban vegetated landscapes (Pittenger and Shaw, 2007). Because coefficients for agricultural crops are derived to maximize crop growth and production, and the goal for landscapes is to identify the minimum amount of water needed to maintain acceptable appearance and function, a distinction is made between coefficients for crops and coefficients for landscape plants. In the case of landscape plants, the adjustment factor is often referred to as a "plant factor" $(P F)$ rather than a crop coefficient $(K c)$ (Pittenger and Shaw, 2007).

\section{Study objectives}

The goal of this study was to better understand how a growing urban forest influences residential landscape water demand. To this end we had two objectives. First, we wanted to estimate residential landscape water demands based on the spatial distribution of different residential landscapes types. To do this we consider water demand a function of the areal extent of residential landscaping, the water-loss rate (i.e. Plant Factors) for different landscaping types, and local climatic factors. Our second objective was to predict the spatial distribution of future urban forest canopy across the same area and to estimate future residential landscape water demands based on the growing urban forest. We used spatial regression models to predict the future areal extent of tree canopy and exposed turf grass, and based on these estimates apply the water demand model to estimate future water demand. An important question we investigate is whether the growing urban forest increases overall 


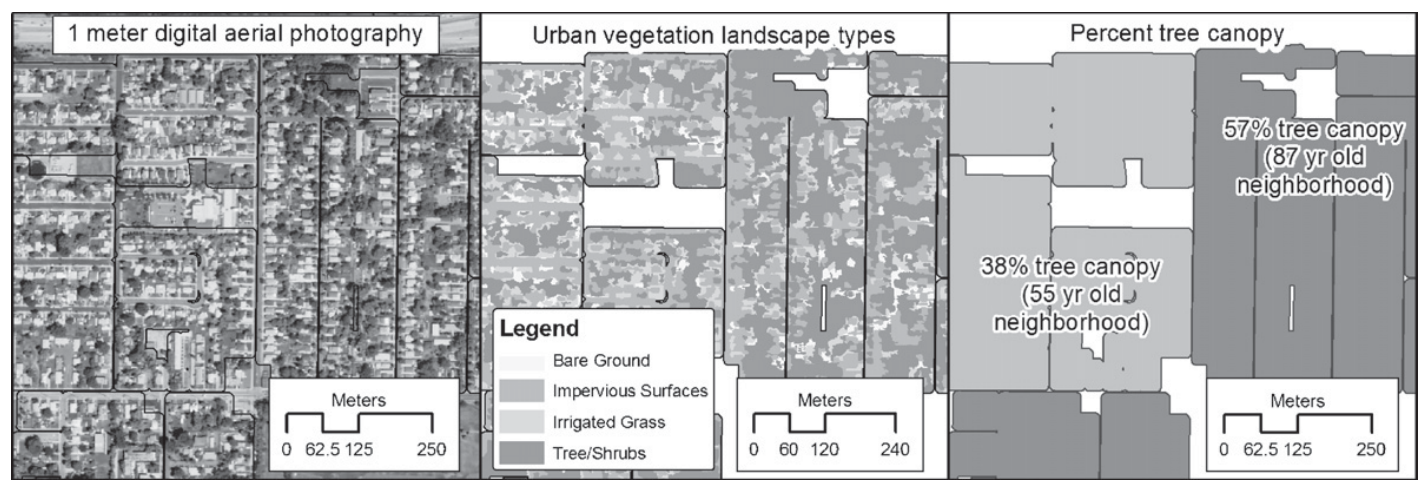

Fig. 1. Urban vegetation classification of 1-m digital orthophotography used to attribute neighborhood polygons.

residential irrigation demand, decreases demand, or has no apparent effect.

\section{Study area}

Salt Lake County, Utah $\left(41^{\circ} \mathrm{N}, 111^{\circ} \mathrm{W}\right)$ is located on the eastern rim of the Great Basin ecoregion of the western United States. The region is considered a temperate desert with a mean annual precipitation of $570 \mathrm{~mm}$ and mean annual reference evapotranspiration of $950 \mathrm{~mm}$ (Banner et al., 2009). Precipitation falls predominantly as snow during the winter months, with very little occurring during the summer growing season from May to September. Capturing spring runoff in reservoirs and aquifers is therefore critical to the region's water supply. The Salt Lake County boundary lies coincident with the Jordan River hydrologic basin, which receives water from the Wasatch Range to the east, the Oquirrh Range to the west, and the headwaters of the Jordan River in the Utah Lake hydrologic basin to the south. Drainage from the Jordan River Basin flows north into the Great Salt Lake. Water supply comes by the way of surface, ground, and imported sources (UDNR-DWR, 2009). Municipal and industrial water use and supply is managed by the Jordan Valley Water Conservancy District, which estimated a total of $356,050,300 \mathrm{~m}^{3}$ (288,653 acre-feet) of reliable potable water supplies for public community systems in 2005 (UDNR-DWR, 2009). Agricultural water uses are managed separately.

Salt Lake County is the most populous county in Utah with an estimated population of nearly a million people in 2005 (U.S. Census Bureau, 2005) and a projected population of 1.6 million by 2050 (Salt Lake County, 2010). The area presents an ideal example of expanding urbanization common in many arid and semi-arid metropolitan cities in the western United States. Following the end of World War II, residential suburbs and associated commercial areas extended from the city's historical center toward the south and west portions of the valley. In 2005 there were 33,631 ha of residential land in the valley compared to 15,593 ha in 1975-a approximate $100 \%$ increase in 30 years (there were 21,867 ha in 1985 and 29,081 ha in 1995 (GIS calculation with residential parcel data, AGRC, 2006)). Nearly all residential expansion has occurred on former agricultural land. Thus, water requirements in the county have shifted markedly from primarily agricultural uses during most of the 20th century to municipal and industrial uses at present and into the foreseeable future (UDNR-DWR, 2009).

Water conservation has been a growing concern, particularly during periods of drought. The period from 2001 to 2004 was a notable drought period, and in 2001 the state initiated a water conservation program involving all municipal and industrial water providers. A key part of the program involved informing the public of water conservation measures primarily for outdoor residential water use (JVWCD, 2010). Conservation efforts typically focused on more efficient irrigation practices rather than modifying landscaping preferences (i.e. shifting from mesic to xeric landscaping).

\section{Methods}

Data

To model residential irrigation water demand we used $1-\mathrm{m}$ resolution color-infrared digital orthophotography (NAIP, 2006), GIS vector polygons for census block groups and residential parcels (AGRC, 2006), and meteorological data (evapotranspiration and precipitation) from two weather stations in the study area (Utah Climate Center, 2010). To evaluate the results of the irrigation demand model, we obtained data on water use from federal (Solley et al., 1988; Solley et al., 1998), state (UDNR-DWR, 2009), and county (SLCo, 1977) water use/supply reports. Reported methods for estimating water use varied, but fundamentally involved calculating the amount of outdoor residential use as a proportion of total water use recorded by a metering system. These data were aggregated for the entire county by year.

Using an object-oriented segmentation approach (Jensen, 2005) we generated an urban vegetation GIS dataset (Fig. 1) from 1-m color-infrared digital orthophotography flown for the entire county in the summer of 2006 (NAIP, 2006). This resulted in an urban vegetation vector GIS polygon dataset. Overall map accuracy for five landscape classes (bare ground, irrigated grass, tree/shrub, impervious surfaces, and water bodies) was 75\% using 1197 reference sites.

A common spatial unit of observation for neighborhood level studies in the U.S. is the census block group (Grove et al., 2006; Troy et al., 2007). Block group boundaries however may include non-residential land uses. Given that our focus was on residential landscapes, we modified the census block group boundary to include only the residential portion of the block group. This created a GIS dataset of 542 "neighborhoods" defined as the residential portion of census block groups. Attributes from the parcels GIS dataset were used to determine the median age of housing stock for each residential neighborhood (Figs. 1 and 2).

To assign a measure of tree/shrub canopy to each residential neighborhood we intersected the urban vegetation GIS dataset (created from orthophotography) with the neighborhood dataset and calculated the proportion (later converted to percent) of the neighborhood covered by tree/shrub canopy (Fig. 1). We also did this for turf grass cover, producing a GIS dataset with 542 neighborhoods, each neighborhood containing an attribute for neighborhood age, percent tree/shrub canopy, and percent grass cover (not undercanopy).

Relative evapotranspiration (ETo) and precipitation data for the entire study area were obtained from two point locations: the 
Table 1

Relative evapotranspiration and precipitation data used to estimate residential irrigation water demand.

\begin{tabular}{|c|c|c|c|c|c|c|c|c|c|c|c|c|}
\hline & \multicolumn{2}{|c|}{ May } & \multicolumn{2}{|c|}{ June } & \multicolumn{2}{|l|}{ July } & \multicolumn{2}{|c|}{ August } & \multicolumn{2}{|c|}{ September } & \multicolumn{2}{|c|}{ Summer Total } \\
\hline & ETo & Precip. & ETo & Precip. & ETo & Precip. & ETo & Precip. & ETo & Precip. & ETo & Precip. \\
\hline \multicolumn{13}{|l|}{1975} \\
\hline Cottonwood Weir & 10.78 & 9.06 & 13.64 & 3.10 & 16.57 & 0.42 & 16.05 & 0.61 & 10.01 & 0.79 & 67.05 & 13.97 \\
\hline SL Int'l Airport & 12.49 & 6.62 & 16.20 & 4.65 & 20.45 & 0.76 & 17.51 & 0.34 & 12.46 & 0.23 & 79.11 & 12.60 \\
\hline Average & 11.64 & 7.84 & 14.92 & 3.87 & 18.51 & 0.59 & 16.78 & 0.48 & 11.24 & 0.51 & 73.08 & 13.28 \\
\hline \multicolumn{13}{|l|}{1985} \\
\hline Cottonwood Weir & 14.73 & 11.96 & 18.04 & 6.41 & 19.63 & 3.20 & 17.05 & 0.00 & 10.62 & 7.95 & 80.08 & 29.53 \\
\hline SL Int'l Airport & 14.94 & 7.61 & 18.37 & 3.31 & 20.40 & 2.22 & 17.59 & 0.09 & 10.48 & 5.07 & 81.79 & 18.30 \\
\hline Average & 14.84 & 9.79 & 18.21 & 4.86 & 20.02 & 2.71 & 17.32 & 0.04 & 10.55 & 6.51 & 80.94 & 23.91 \\
\hline \multicolumn{13}{|l|}{1995} \\
\hline Cottonwood Weir & 12.02 & 17.55 & 15.07 & 7.26 & 18.10 & 1.92 & 16.57 & 0.28 & 11.83 & 3.73 & 73.59 & 30.75 \\
\hline SL Int'l Airport & 12.15 & 9.41 & 15.83 & 3.84 & 20.06 & 0.86 & 18.32 & 0.60 & 11.14 & 3.43 & 77.50 & 18.14 \\
\hline Average & 12.08 & 13.48 & 15.45 & 5.55 & 19.08 & 1.39 & 17.45 & 0.44 & 11.49 & 3.58 & 75.54 & 24.44 \\
\hline \multicolumn{13}{|l|}{2005} \\
\hline Cottonwood Weir & 13.39 & 12.78 & 15.35 & 6.39 & 18.74 & 0.00 & 15.28 & 0.66 & 10.86 & 3.86 & 73.61 & 23.69 \\
\hline SL Int'l Airport & 13.59 & 7.39 & 16.22 & 4.25 & 21.19 & 0.05 & 17.12 & 1.88 & 11.63 & 1.04 & 79.74 & 14.62 \\
\hline Average & 13.49 & 10.08 & 15.78 & 5.32 & 19.96 & 0.03 & 16.20 & 1.27 & 11.25 & 2.45 & 76.68 & 19.15 \\
\hline \multicolumn{13}{|c|}{30 yr Ave. (1979-2009) } \\
\hline Cottonwood Weir & 14.30 & 7.80 & 17.42 & 3.84 & 19.51 & 2.67 & 16.94 & 2.79 & 11.38 & 4.88 & 79.55 & 21.97 \\
\hline SL Int'l Airport & 14.71 & 5.00 & 18.24 & 2.46 & 20.98 & 1.70 & 18.03 & 1.68 & 12.07 & 3.12 & 84.02 & 13.97 \\
\hline Average & 14.50 & 6.40 & 17.83 & 3.15 & 20.24 & 2.18 & 17.49 & 2.24 & 11.72 & 4.00 & 81.79 & 17.97 \\
\hline
\end{tabular}

Note: Units reported in centimeters. Average of the recordings from the two stations is in italics.

Salt Lake International Airport $(1287 \mathrm{~m})$ and Cottonwood Weir (1511 m) weather stations (Utah Climate Center, 2010). The Salt Lake International Airport station is representative of the valley bottom and the drier western portion of the study area, while the Cottonwood Weir station, near the mouth of Big Cottonwood

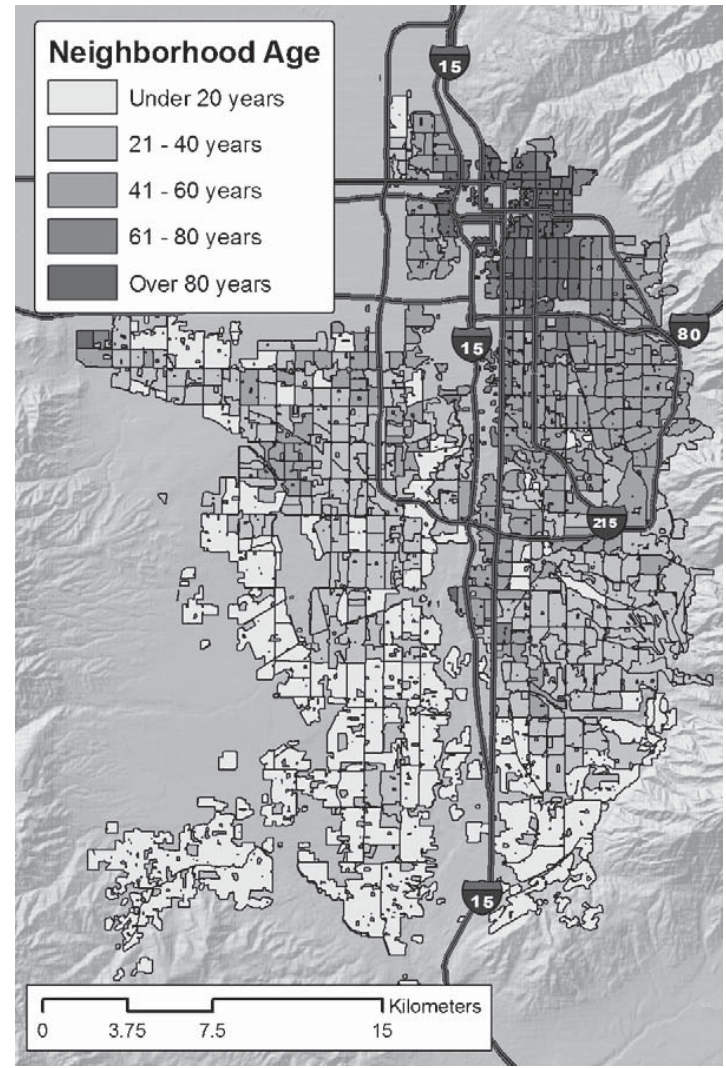

Fig. 2. Map of metropolitan Salt Lake County, USA showing median age of housing stock by neighborhood.
Canyon, is representative of the more mesic foothills on the east side of the valley. We experimented with a spatial interpolation approach to create continuous GIS datasets of ETo and precipitation, with which we could apply an ETo and precipitation value to each neighborhood, but found that approach did not produce results that were appreciably better than simply taking the average of the two weather stations and applying those values to each neighborhood in the entire valley. In other words, the data for ETo and precipitation we used was an average of the two weather stations, which we considered representative of the range of evaporative and precipitation conditions in the Salt Lake Valley. Table 1 presents the climate data used in our study.

\section{Estimating irrigation water demand}

To estimate water demand for residential landscapes we used a modification of the approach used by (Endter-Wada et al., 2008) and pioneered by the Irvine Ranch Water District in Southern California to establish water rate structures (Wong, 1999). Eq. (1) estimates the amount of irrigation water required to replace water used by the vegetated landscape:

$I_{m}=\sum_{L=1}^{y}\left(\left(\left(P F_{L} \times E T o_{m}\right)-R_{m}\right) \times\left(\frac{A_{L}}{D U}\right)\right)$

where $I_{m}=$ total irrigation demand for month $m ; y=$ total number of landscape types $L ; P F_{L}=$ plant factor or "crop coefficient" for landscape type $L ; \mathrm{ETo}_{m}=$ total reference evapotranspiration for month $m ; R_{m}=$ total rainfall (precipitation) for month $m ; A_{L}=$ area of landscape type $L ; D U=$ distribution uniformity (irrigation inefficiency) factor.

Measurements for landscape area $\left(A_{L}\right)$ came from the urban vegetation GIS dataset, and $\mathrm{ETo}_{m}$ and precipitation $\left(R_{m}\right)$ from the weather station data. The choice of parameters for $P F_{L}$ and $D U$ was guided by the work by others (Kneebone et al., 1992; Costello and Jones, 1994; Farag, 2003; Montague et al., 2004; Endter-Wada et al., 2008). A reasonable $P F$ for warm season turf grass ranges between 0.80 and 0.90 (Kneebone et al., 1992). Few studies have reported adjustment factors for trees and woody plants partly because of the wide variety of species found in urban landscapes (Kjelgren 
et al., 2000). Costello and Jones (1994) suggested factors ranging from 0.20 to 0.80 . Largely consistent with that range, Montague et al. (2004) and Kjelgren et al. (2005) reported empirical Plant Factors for broadleaf deciduous species that ranged from 0.2 for Acer platanoides to 1.0 for Salix matsudana. In the absence of clear standards for Plant Factors for urban non-turf vegetation, we used a PF 0.50 for tree/shrub canopy as a reasonable mid-point of the suggested (Costello and Jones, 1994) and empirically demonstrated ranges (Montague et al., 2004; Kjelgren et al., 2005). Following Farag (2003) we used a PF of 0.80 for exposed turf grass and a PF of 0.40 for grass under tree canopy. Thus, the combined $P F$ for areas considered having both tree canopy and under canopy turf grass have a $P F$ of 0.90 . Distribution Uniformity $(D U)$ is an inefficiency factor that takes into consideration the non-uniformity with which most urban irrigation systems apply water to urban landscapes. We used a $D U$ factor of 0.75 , which assumes that the irrigation systems for the residential neighborhoods in our study are on average $75 \%$ efficient (Irrigation Association, 2010).

Using Eq. (1), we estimated residential landscape water demand for each neighborhood. For turf grass and tree/shrub canopy we used the measured area provided by the GIS dataset, for turf grass under tree canopy we used $60 \%$ of the area that was tree/shrub canopy. While the date of the imagery from which the urban vegetation GIS dataset was generated was 2006, we estimated water demand for 2005 (using 2005 ETo and precipitation) because a reliable report on municipal water use was available for 2005 and not for 2006. This allowed us to compare our estimates to reported water use data and a means to validate our modeling approach. We considered it reasonable to assume that vegetation cover did not change significantly between 2005 and 2006. It should be noted that this approach used the measured data from the urban vegetation GIS dataset. Since we have measured landscape data for only one year, our next step was to develop models to predict future quantities of the three landscape types (grass under canopy, exposed grass, and tree/shrub canopy) used by the water demand model (i.e. Eq. (1)).

\section{Relationship of tree canopy and grass cover to neighborhood age}

The plots in Fig. 3 were created from the GIS dataset of 542 neighborhoods containing attributes for neighborhood age, percent tree canopy, and grass cover. As observed by others (Maco and McPherson, 2002; Grove et al., 2006; Troy et al., 2007), the relationship between neighborhood age and percent canopy cover is curvilinear and appears to reach an asymptote of 50\% tree canopy at about 100 years. The grass cover-to-neighborhood age relationship is nearly the reciprocal of the tree canopy cover relationship, with low grass cover in older neighborhoods and higher grass cover in newer neighborhoods.

After running diagnostics required for linear regression analysis (Faraway, 2005), we fit regression models to both the tree canopy and grass cover data. Because we were using spatial data and used all the neighborhoods in the study area as observations, we tested model residuals for spatial dependence. Finding high positive spatial autocorrelation in our data, we adopted a simultaneous autoregressive model (SAR) for the regression analysis using spatial weights defined by the nearest neighborhood centroid (Bivand et al., 2008). We found that a quadratic term for neighborhood age as the independent variable fit the data well, and used the following equations to model the dependent variables percent tree canopy (Eq. (2)), and percent grass cover (Eq. (3)):

PercentTC $\sim 19.94+$ Age $\times 0.41774+$ Age $^{2} \times-0.00134$

PercentGC $\sim 36.17+$ Age $\times-0.24965+$ Age $^{2} \times-0.00308$

Because spatial regression models with SAR use a maximum likelihood estimator instead of ordinary least squares, the com-
Tree Canopy Neighborhood Age

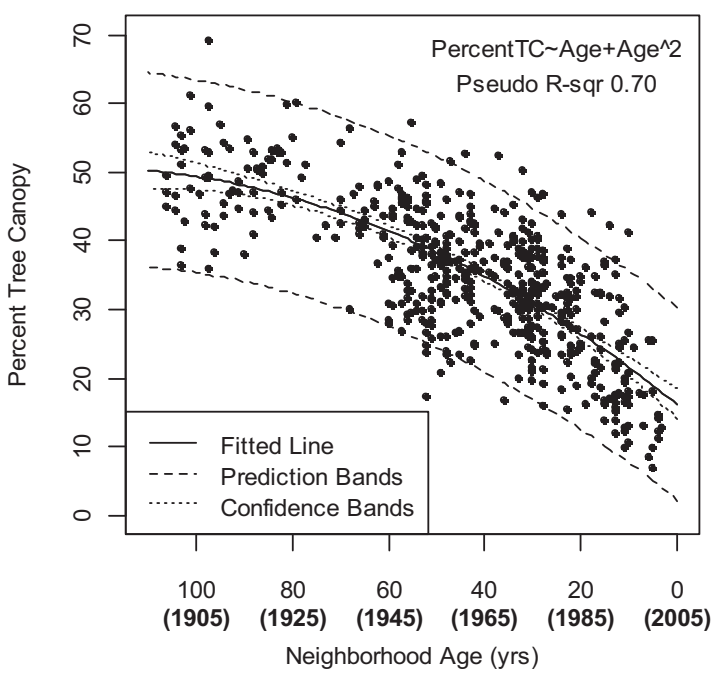

Grass Cover Neighborhood Age

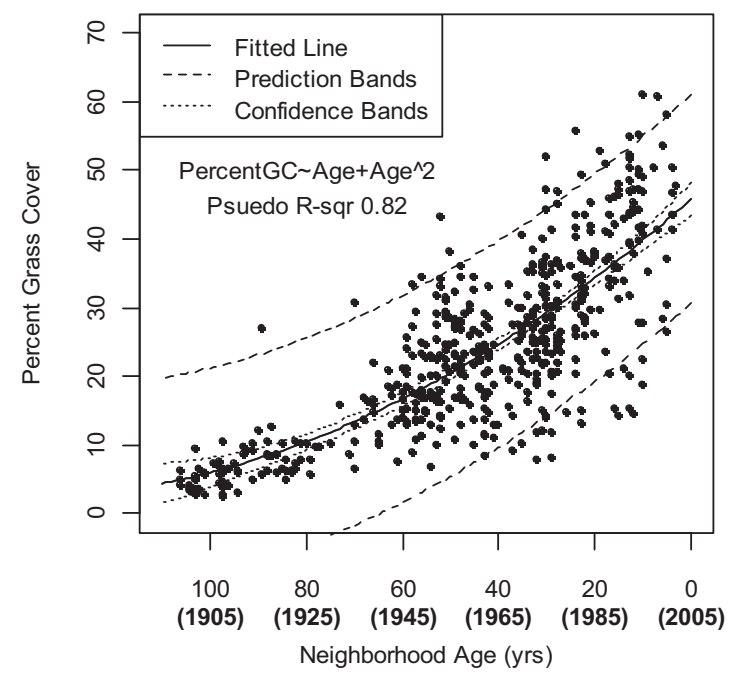

Fig. 3. Plots showing the relationship of tree canopy to neighborhood age, and exposed turf grass cover to neighborhood age.

monly reported goodness-of-fit statistic, $R^{2}$, is not produced. We calculated Pseudo $R^{2}$ as the square of the correlation between the fitted and actual value for the dependent variable (Anselin, 1988). This produced goodness-of-fit measures of 0.70 and 0.82 for the tree canopy and grass cover models, respectively.

\section{Model validation (back-casting)}

Using Eqs. (2) and (3) we predicted past tree canopy and grass cover by subtracting years from the Age parameter in the regression model and applying the model to all neighborhoods in the study area. To obtain the area of a given landscape type (e.g. tree/shrub canopy) in a neighborhood we converted the predicted percent to a proportion and multiplied the proportion by the total area of the neighborhood. With this approach we tested our combined water demand/landscape prediction model by back-casting tree canopy 


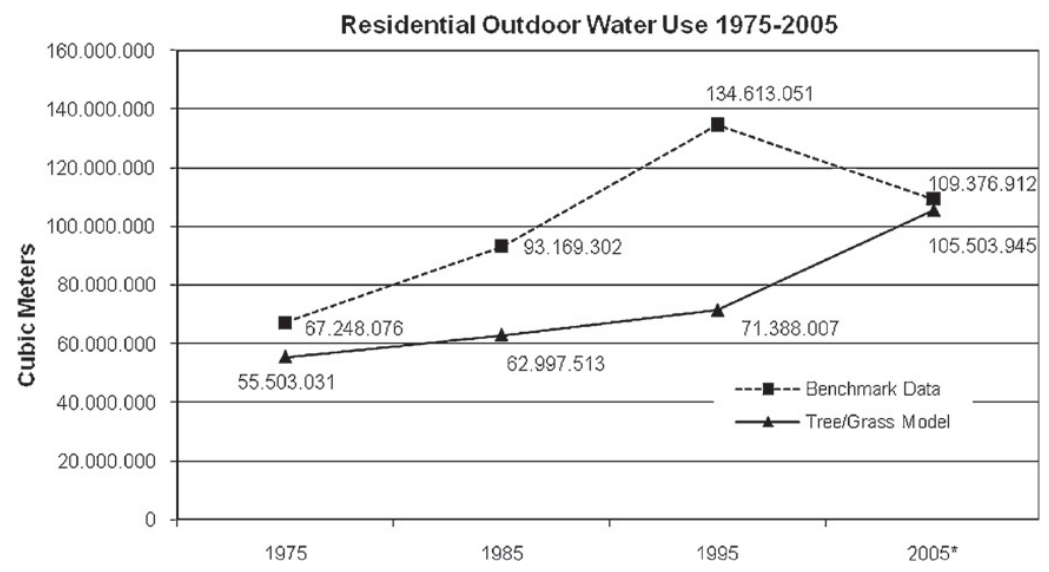

Fig. 4. Plot of predicted residential irrigation water demand compared to benchmark reported water use for 1975-2005.

and grass cover using the regression models, calculating grass under tree canopy as $60 \%$ of tree canopy, and then applying the water demand model (Eq. (1)) using the predicted landscape areas. We did this for three dates for which we could obtain water use data to use as a benchmark for validation (SLCo, 1977; Solley et al., 1988; Solley et al., 1998). Water use data for previous years did not report residential outdoor use separately as did the report for 2005 (UDNR-DWR, 2009) so we estimated residential outdoor use for past years based on the proportion of municipal water use reported as residential outdoor use in 2005. In $2005109,376,912 \mathrm{~m}^{3}$ of a total $276,324,973 \mathrm{~m}^{3}$, or $39 \%$ of municipal water, was used for residential outdoor purposes. Using this fraction we calculated the amount of water that was likely used for residential outdoor purposes based on total municipal water use reported in 1975 (SLCo, 1977), 1985 (Solley et al., 1988), and 1995 (Solley et al., 1998).

\section{Predicting forest growth and forecasting water demand}

To explore the effects of a maturing urban forest on water demand we predicted future tree/shrub canopy and turf grass cover using the spatial regression models (Eqs. (2) and (3)) and undercanopy turf estimated at $60 \%$ of predicted tree/shrub canopy. We then used the predicted amounts of tree/shrub, exposed turf grass, and under-canopy turf grass in the water demand model (Eq. (1)) to forecast estimated water demand for ten-year increments from 2010 to 2050. We used 30 year (1979-2009) averages for ETo and precipitation. We did this for two residential growth scenarios.

The first scenario assumed no additional residential growth in the Salt Lake Valley. While unrealistic, this scenario allows us to evaluate the changing composition of the three landscape types while holding residential growth constant, thus isolating the effects of a maturing urban forest on overall landscape water demand.

The second scenario assumed residential growth, allowing us to explore the effects a growing and maturing forest on residential water demand under more realistic conditions of expanding urbanization. Future residential expansion is likely to occur in the southwest section of the valley and in a few islands of farmland currently surrounded by residential development. To simulate future residential growth we identified areas (polygons) that are likely to be developed as residential neighborhoods based on their zoning designation within the county parcels GIS dataset. During the decade from 1995 to 2005 approximately 4500 ha of new residential land was developed in the study area. Based on this figure we simulated residential growth by adding an additional 4000 ha of residential development for each decade from 2010 to 2050. The exact location of the polygons is not critical for the water demand model since water demand depends only on the area of landscape type. However, the spatial configuration of the simulated neighborhoods is an important requirement when applying the simultaneous autoregressive regression (SAR) model for prediction. For this reason we simulated new neighborhoods with spatial structure and size similar to that of existing neighborhoods.

\section{Results}

Fig. 4 presents the results of our back-cast validation using the tree/shrub and grass regression models (Eqs. (2) and (3)) to predict residential irrigation water demand based on landscape types. For 2005 , the model's estimate is very close to the benchmark reported amount of water for outdoor residential uses. Based on predicted tree/shrub canopy and grass cover (i.e. using regression coefficients to estimate landscape area) the model estimated irrigation demand at $105,505,945 \mathrm{~m}^{3}$ for the months of May-September. Based on measured GIS data (i.e. classified digital aerial photography) the model estimated irrigation demand at $109,979,112 \mathrm{~m}^{3}$. Reported outdoor residential use for the entire year was $109,376,912 \mathrm{~m}^{3}$ (88,672 acre-feet) (UDNR-DWR, 2009). Model estimates for the other three benchmark dates $(1977,1985,1995)$ are not as close to reported water use (Fig. 4).

\section{Results for the 1995-2005 time period}

The influence of climatic conditions on the model is demonstrated by a comparison of predicted water demand for 1995 and predicted water demand for 2005 (Fig. 4). New residential land development held relatively steady at a rate of $40 \%$ increase for the 1975-1985 decade and 33\% increase for the 1985-1995 decade, then dropped to $16 \%$ increase during the decade from 1995 to 2005 (GIS calculation with residential parcel data, AGRC, 2006). If the total area of residential development were the only factor influencing water demand, we would expect the rate of increasing water demand (i.e. slope between 1995 and 2005) to drop or at least remain constant given a slowing of residential growth for the 1995-2005 time period. Instead the model suggests there is a $48 \%$ increase in water demand between 1995 and 2005. To understand why water demand increased at a faster rate than residential growth rate, we looked at the climate data (Table 1) and found the summer of 2005 to be hotter and drier than the summer of 1995 (the difference between ETo and precipitation was greater in 2005 for four of the five months). To determine whether climatic factors influenced our water demand prediction, we ran the model again for 2005 using 1995 climate data and found the increased demand 


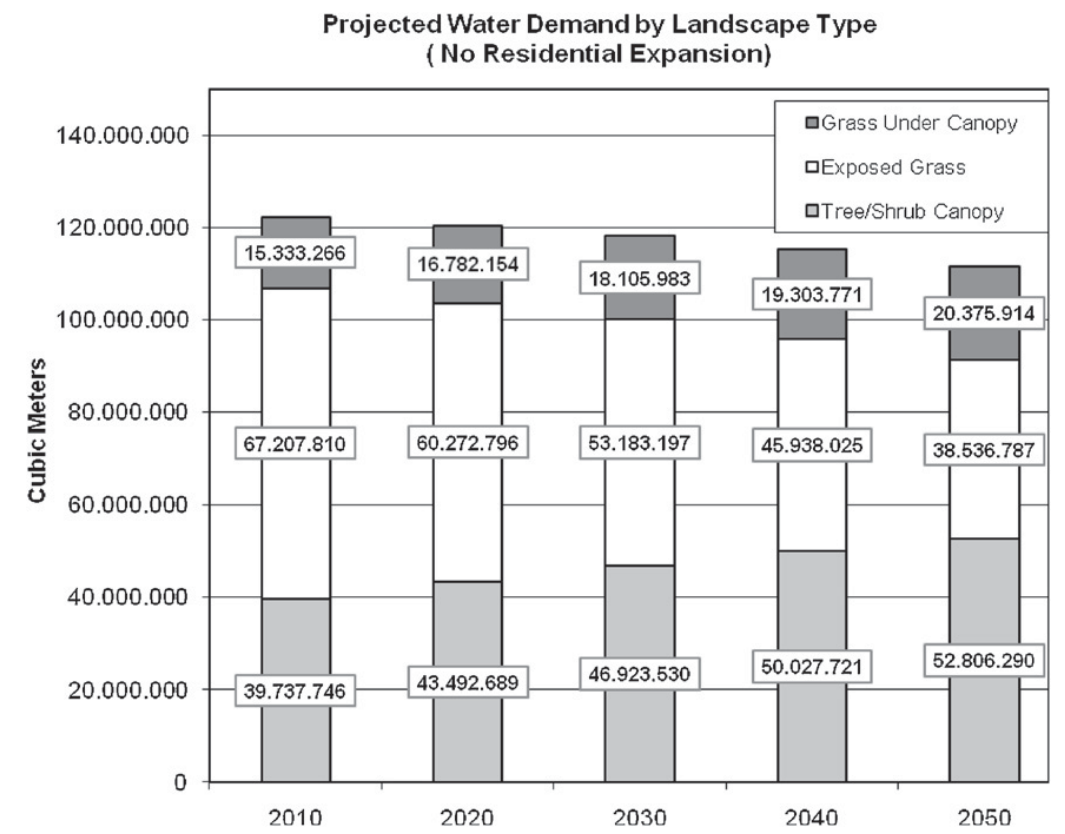

Fig. 5. Estimated water demand from 2010 to 2050 under hypothetical scenario of no residential expansion.

in 2005 to be only $11 \%$-demand that would be accounted for by the relatively moderate increase (16\%) in residential land development. This suggests that the model is sensitive to climatic conditions as well as increases in residential development.

Notable in Fig. 4 is a sharp decrease in benchmark water use reported for the years 1995 and 2005 (Solley et al., 1998; UDNR-DWR, 2009). As described previously the region experienced significant drought conditions from 2001 to 2004, which motivated the state to implement the "Slow the Flow: Save $\mathrm{H}_{2} \mathrm{O}^{\text {" water con- }}$ servation effort (JVWCD, 2010). As a result of the program, water conservation increased through the middle part of the decade and per capita water consumption declined (JVWCD, 2011). The trend toward lower per capita water use has since leveled off with the return of wetter years and water agencies developing their own water conservation programs.

\section{Effects of a maturing urban forest on water demand}

Fig. 5 presents a graph of projected water demand based on predicted amounts of tree/shrub canopy, turf grass, and under-canopy turf for the years 2010-2050 under the hypothetical "no residential expansion" scenario. The graph illustrates that as the abundance of tree/shrub (i.e. woody plants) increases and the amount of turf grass cover decreases through time, overall water demand decreases slightly. In reference to the entire study area, this of course applies under the condition that there is no residential expansion in the Salt Lake Valley. However, by inference it suggests that the net effect of a maturing forest in a neighborhood, or bounded section of the city, is a decline in irrigation water demand. This is explained by the relative differences in which the model accounts for water lost through

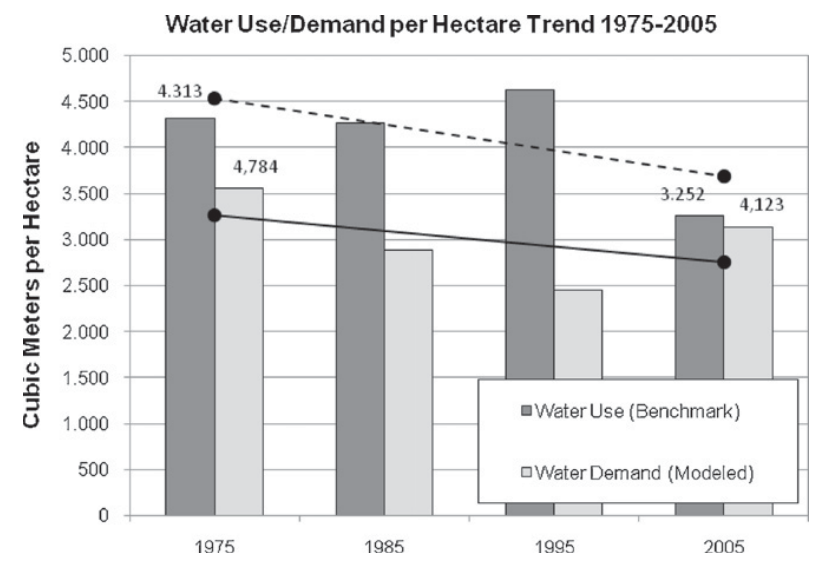

Fig. 6. Trend of water use (benchmark) and water demand (modeled) per hectare of residential land use for 1975-2005.

evapotranspiration by tree/shrub (woody plants), turf grass, and turf grass under-canopy and changes in the overall composition of these landscape types as the urban forest matures.

To better understand the effects of increasing tree canopy and decreasing turf grass area, it is important to evaluate water demand relative to total land area under irrigation. Table 2 presents an estimate of total area (ha) in residential land use for the years 1975-2005 based on parcel GIS data. Also presented are the totals for these dates for predicted irrigation water demand, and the benchmark water use data. As can be seen, irrigation water required per hectare decreases between 1975 and 1985, and between 1985

Table 2

Total residential land area, benchmark water use data, and modeled water demand data for 1975-2005.

\begin{tabular}{llcrr}
\hline Year & Residential land area (ha) & Modeled water demand $\left(\mathrm{m}^{3}\right)$ & Water demand $\left(\mathrm{m}^{3} /\right.$ ha $)$ & Benchmark water use $\left(\mathrm{m}^{3}\right)$ \\
\hline 1975 & 15,593 & $55,503,031$ & 3559 & $67,248,076$ \\
1985 & 21,867 & $62,997,513$ & 2881 & $93,169,302$ \\
1995 & 29,081 & $71,388,007$ & 2455 & $134,613,051$ \\
2005 & 33,631 & $105,503,945$ & 3137 & 4261 \\
\hline
\end{tabular}


and 1995 . Demand increases however in 2005, which can probably be explained by the exceptionally dry climatic conditions that year. The per-unit-area trend in both water demand and water use for the decades 1975-2005 are graphed in Fig. 6.

\section{Estimating future residential water demand based on landscape} needs

Fig. 7 presents maps of predicted urban vegetation change and water demand for 2010 and 2040 based on simulated residential growth at a rate of 4000 ha per decade. Projections of water demand by landscape type are presented in Fig. 8. Unlike Fig. 5 we see a steady increase in water demand for all three landscape types due to the increasing area of land in residential development that will require irrigation. Fig. 9 presents the model's prediction of residential landscape water demand from 1975 to 2050 with simulated residential expansion (linear growth at 4000 ha/decade).

While uncertainty exists in several components of the model, it is only possible to measure uncertainty associated with the regression components of the vegetation prediction model. Fig. 9 shows the upper and lower bounds of uncertainty attributed to the regression predictions for tree/shrub canopy and grass cover. These bounds were computed by determining pseudo prediction intervals at 95\% confidence for the regression models (Eqs. (2) and (3)) and calculating water demand at decennial intervals based on tree/shrub canopy and grass cover predictions within that range of uncertainty.

\section{Discussion}

Water conservation is an important concern in many arid and semiarid cities in the United States and other parts of the world (Gleick, 2000). As urban populations grow and many parts of the world face the prospect of water scarcity (Vorosmarty et al., 2000) it is crucial that municipalities be forward-thinking in their assessment of both water consumption and water supply. This study makes at least three important contributions to the discussion of water scarcity in metropolitan areas. First, we demonstrate that as an urban landscape matures over time the proportion of vegetated landscape components shifts from turf grass to predominantly tree canopy cover, and this shift in turn influences landscape irrigation requirements. Second, municipalities must begin thinking of their municipal water budget not in terms of how much water homeowners consume, but how much is really needed, particularly for irrigated landscapes. Landscape water budgeting as described in this study is perhaps the most practical approach to estimating landscape water needs as the product of local ETo and appropriate plant correction factors. Third, we suggest that policies encouraging substituting trees and woody plants for turf grass in new residential developments are likely to show the greatest benefits from these policies after some time has elapsed.

Data on tree canopy and neighborhood age show that over time the landscape area of urban tree/shrub canopy increases, and similar data suggest the amount of exposed turf grass decreases (Fig. 3). It is important to note that two things are occurring. First, the amount of exposed turf grass decreases because it is being replaced and covered by tree/shrub canopy, and second, the landscape area of trees and other woody plants increases as these landscape components mature. The landscape area of turf grass in existing landscapes does not typically increase with time.

The projected decrease in landscape water demand can be explained in large part by the increasing landscape area of trees/shrubs, which were given a 0.5 PF in the water demand model. Given the semiarid climate and diversity of woody plant species in Salt Lake County this is a reasonable water-loss factor for this urban environment. Growing season daytime low relative humidities are often between 10 and 15\%, translating to saturation deficits $(S D)$ of 3-4 kPa. High $S D$ levels above $\sim 2 \mathrm{kPa}$ imposed at the leaf level in well-ventilated woody plants cause stomata in most tree species to act like circuit breakers (Turner et al., 1984). This response has been shown to moderate overall tree water loss at large $S D$ levels such that plant water use can exhibit a dose response to increasing ETo (Choudhury and Monteith, 1986). Differential stomatal sensitivity to $S D$ accounted for the wide variation in $P F$ s for broadleaf species reported by Montague et al. (2004) also in Utah, such that a 0.5 $P F$ represents a reasonable convergence that could be expected in a typical urban forest in a semiarid environment with a wide diversity of species. In a more humid climate, however, with lower growing season $S D$, an appropriate $P F$ would likely need to be somewhat higher, possibly 0.6-0.7. This suggests that in more humid climates trees and woody plants may have less of an impact on irrigation water demand than in semiarid regions.

Greater tree canopy without underlying turf grass gives the urban water manager greater flexibility in managing times of uncertain water supplies, such as during drought. The need for uniform appearance and limited drought tolerance of cool season turf in Salt Lake County's high desert temperate climate sets a definite floor of water needs. While representing a much greater investment than turf grass, a mature urban forest canopy affords more leeway in how it is irrigated. Similar to partial root zone irrigation in fruit crops (Sepaskhah and Ahmadi, 2010) woody landscape plants do not need uniform water application to maintain adequate water uptake and plant health, unlike turf grass, thus saving substantial water. Also, because of their more extensive root system (relative to turf grass) trees and shrubs are capable of exploiting a larger volume of soil moisture, and as such do not deplete soil water and become water stressed as rapidly as turf grass (St. Hilaire et al., 2008). Few tree species show mild water stress symptoms allowing for deficit irrigation, reducing demand and enhancing the ability of forested landscapes to withstand drought (Sachs et al., 1975).

Landscape irrigation comprises a significant portion of many municipalities' water budgets (Bishop and Hughes, 1993; Vickers, 1991; Hanak and Davis, 2006) and in arid states such as Nevada accounts for the single most consumptive use in the state (Sovocool et al., 2006). Through improvements in application technology, water policy, and implementation of more water-efficient landscapes, it is also one of the most promising segments of the urban water budget for conservation (St. Hilaire et al., 2008; Endter-Wada et al., 2008). Municipalities, however, often include landscape irrigation as part of "residential outdoor use" assuming it comprises the largest portion of that category (UDNR-DWR, 2009). In some parts of the country, however, significant amounts of residential outdoor water may be used for swimming pools (Wentz and Gober, 2007). It is also common to find more irrigation water applied to residential and commercial landscapes than what is required for healthy maintenance (Farag et al., in press). Over-irrigation occurs when irrigation water is applied non-uniformly (Baum et al., 2005) and when automatic sprinkler systems apply water after adequate precipitation, or even while it is raining (Kjelgren et al., 2000).

While we used reported estimates of residential outdoor water use in our study as a benchmark with which to compare the results of our water irrigation demand model, we recognize that the comparison is not exact. Given what we know about the differences between how much water is reported as "residential outdoor use" and what is in fact required to maintain healthy landscape vegetation, we would expect our irrigation demand model to estimate amounts below the amount reported. Indeed, this might account for the large differences between our predicted irrigation demand and reported water use for the years 1975, 1985, and 1995 (Fig. 4). How much of a difference one should expect would require accounting for non-irrigation outdoor residential water uses, and estimat- 


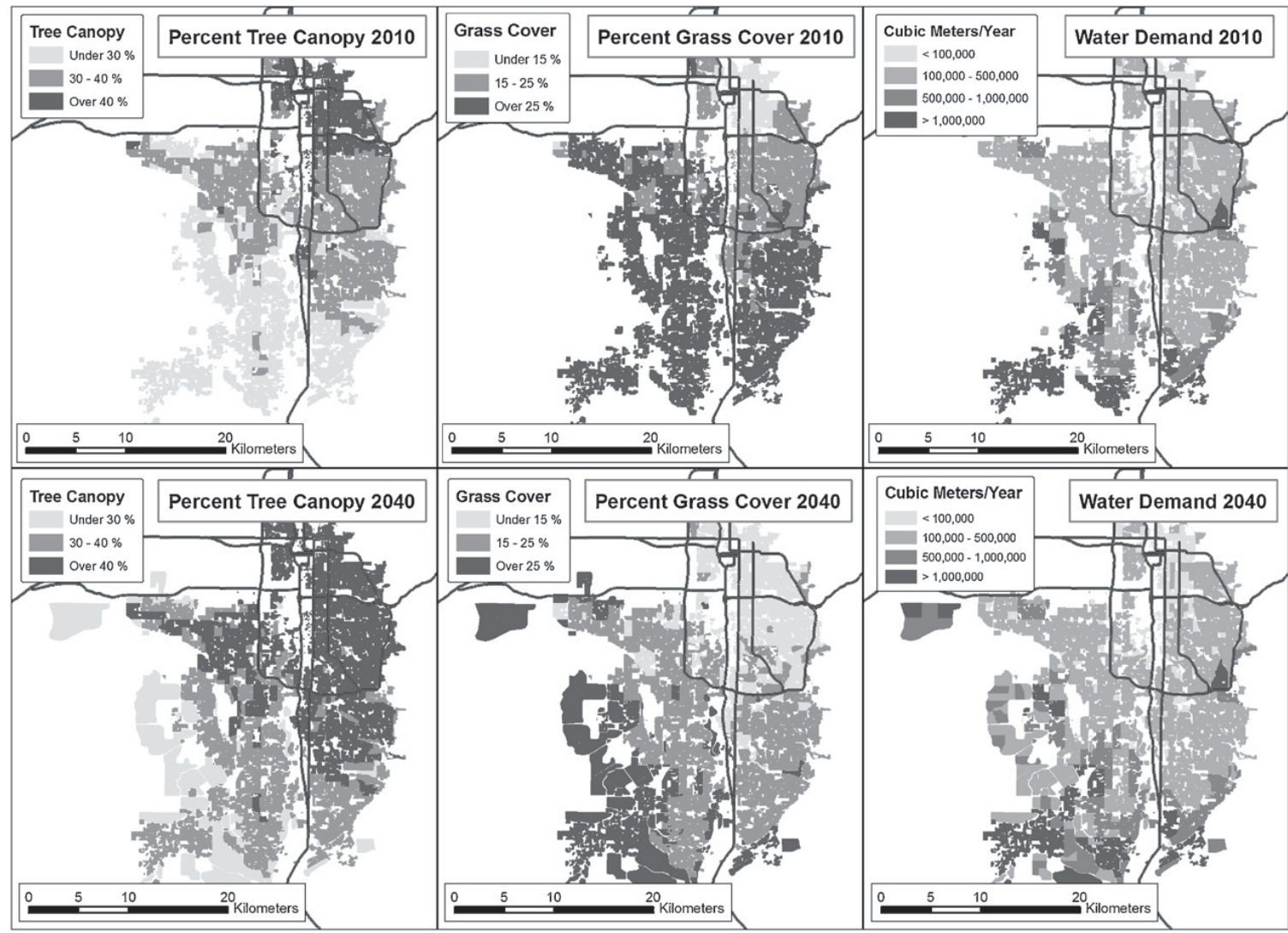

Fig. 7. Maps of predicted tree canopy, turf grass cover, and water demand for 2010 and 2040 with simulated residential growth.

ing how much over-irrigation occurs. Over-irrigation estimates in another Utah study found that it was common for homeowners to apply up to $15 \%$ excess water to residential landscapes, with an extreme case of one homeowner applying 70\% excess water (Endter-Wada et al., 2008). The important point we would like to make is that municipalities must begin thinking of their water budget not in terms of how much water homeowners consume, but how much is really needed for landscape irrigation.
Separate accounting of non-irrigation outdoor use from landscape irrigation use will be helpful, but in addition, a landscape water budget approach, similar to the water budget described by Eq. (1), will provide municipalities realistic target water allowances for maximum water conservation. Improvements to this approach are certainly needed, particularly in the area of determining empirically based water-loss coefficients (i.e. Plant Factors) for urban tree and woody vegetation (Pannuk et al., 2010). Accurate

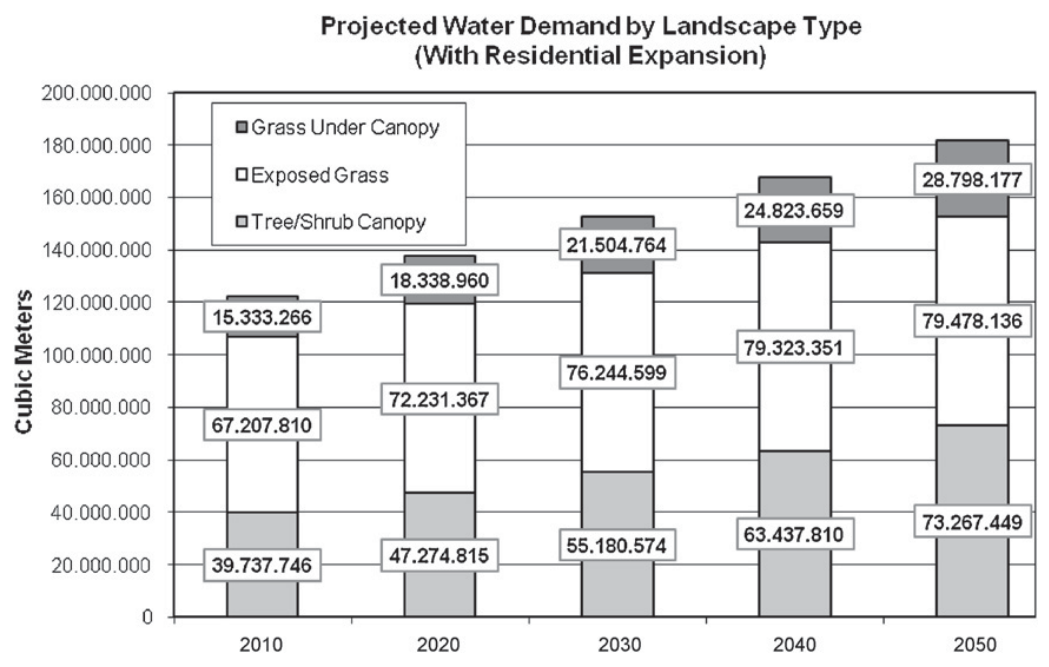

Fig. 8. Estimated water demand from 2010 to 2050 with simulated residential expansion. 


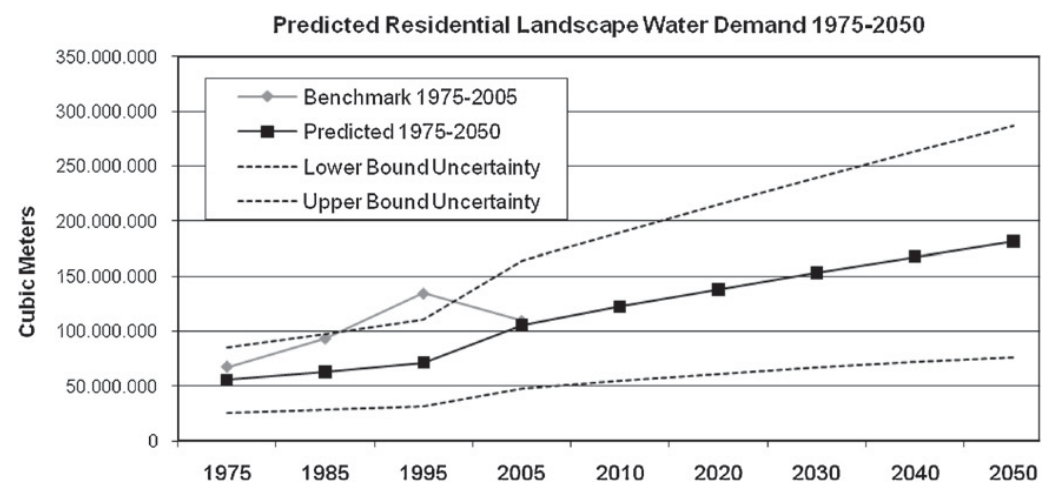

Fig. 9. Plot of estimated irrigation water demand for all of metropolitan Salt Lake County from 1975 to 2050.

measurements of under-canopy turf grass are difficult to obtain, but could improve confidence model results. Farag et al. (in press) used multispectral imagery acquired prior to full leaf out (early May) and after full leaf out (September) to estimate under-canopy turf grass area. Their findings suggest that shaded turf grass can account for between 20 and $68 \%$ of the area in municipal landscapes (Farag et al., in press).

An important and effective measure municipalities can take to improve water conservation in residential landscapes is through legislating or encouraging more water-efficient landscapes (St. Hilaire et al., 2008). Ordinances requiring water-efficient landscaping are becoming more common (Abbey, 1998) and several municipalities have offered monetary incentives to homeowners who convert turf grass to more water-efficient landscaping (Addink, 2010). Homeowner's choices for landscaping types are primarily motivated by what they consider attractive and comfortable (Hurd et al., 2006; Larson et al., 2009). However, in arid and semiarid urban environments water-conserving landscapes are often not perceived as aesthetically pleasing (Lockett et al., 2002; Larson et al., 2009) so there is a reluctance, even by environmentally conscious homeowners, to adopt landscaping that is more water-efficient (Larson et al., 2009). Converting existing landscapes to more water-efficient landscapes often meets homeowner resistance. An effective way to deal with this problem is to mandate conservation measures be put in place while residential subdivisions are being planned (Arendt, 1999). It has been shown that people prefer landscapes with trees, as opposed to landscapes without them (Dwyer et al., 1991; Kaplan, 1985; Schroeder and Cannon, 1987; Spinti et al., 2004). A potential problem with encouraging homeowners to plant trees is that they are costly and the benefits (economic, aesthetic, etc.) are not immediately apparent. People tend to prefer trees that provide shade and protection from the sun (Lohr et al., 2004) and newly planted trees typically offer little shade. Homeowners should be reminded that in addition to the aesthetic benefits offered by trees and shrubs as they mature, maturing trees and other woody vegetation offer potential economic benefits through water conservation.

\section{Conclusion and future work}

This study presents an innovative approach to better understand how residential water demand is influenced by a growing urban forest. As cities throughout the world encourage the cultivation of urban trees, it is important to more fully understand the consequences of these actions. We used a modeling approach with the purpose of elucidating major factors involved in the growth of an urban forest at a large landscape scale in an urban environment. As a result of our efforts we conclude that irrigation water demand is governed largely by the areal extent of irrigated landscapes, and increased urban forest abundance over time within a fixed area may decrease demand. Our study also serves to identify a number of areas where further research, using alternative methodological approaches at different scales of analysis, would be of significant value.

Improvements to this effort could focus on two areas: (1) better parameterization of the irrigation water demand model for urban residential landscapes, and (2) improved forecasting with better data on future urban landscape conditions. While water-loss coefficients are available for a number of crop plants (Allen et al., 1998) they are lacking for horticultural and landscape plants (Kjelgren et al., 2000). As the concept of a water-loss coefficient, or Plant Factor $(P F)$, becomes more heavily utilized for landscape management in urban areas (Pittenger and Shaw, 2007) there is need for more reliable coefficients. Lacking in particular are reliable coefficients for trees and woody plants. Both will be challenging to derive due to the variety of tree/shrub species common to most urban landscapes and concomitant range of water use rates (Montague et al., 2004; Kjelgren et al., 2005). Another parameter in the irrigation water demand model requiring further study is the Distribution Uniformity $(D U)$ factor. Low $D U$ is a major driver for excess irrigation in uniform turf grass landscapes (Baum et al., 2005). Factors that affect $D U$ are not well understood, but are likely to include neighborhood and irrigation systems age, and possibly housing density and residents' socio-economic group. $D U$ becomes less of a driver for excess irrigation in tree and other woody plant landscapes because their uniform canopies and root zones do not require uniform water application (Sepaskhah and Ahmadi, 2010).

The second area of improvement should focus on using the landscape irrigation water demand model for predictive modeling. Our analysis of projected future water demands are based on linear growth in residential development, and 30 year averages for ETo and precipitation. Both are rough approximations of actual growth and potential future climatic conditions. Given the sensitivity of the model to these two components, as evidenced by fluctuation during the 1995-2005 period, there would be merit in running the landscape water demand prediction using more reliable estimates of land use change and predicted future climatic conditions. This could be carried out by coupling the model described in this paper with reliable land use change and climate change models.

\section{Acknowledgments}

This research was funded by the Intermountain Digital Image Archive Center, Utah State University under grant from NASA (NNX06AF56G). We gratefully acknowledge the helpful critique of earlier drafts of this manuscript by two anonymous reviewers. 


\section{References}

Abbey, D.G., 1998. U.S. Landscape Ordinances: An Annotated Reference Handbook. John Wiley and Sons, New York, NY.

Addink, S., 2010. 'Cash for Grass' - A Cost Effective Method to Conserve Landscape Water?, Retrieved February 11th, 2010 from: http://ucrturf.ucr.edu/ topics/Cash-for-Grass.pdf.

AGRC, 2006. Utah Automated Geographic Reference Center. Retrieved June 1st, 2007 from: http://agrc.its.state.ut.us/.

Allen, R.G., Pereira, L.S., Raes, D., Smith, M., 1998. Crop Evapotranspiration - Guidelines for Computing Crop Water Requirements - FAO Irrigation and Drainage Paper 56. FAO - Food and Agriculture Organization of the United Nations, Rome.

Anselin, L., 1988. Spatial Econometrics: Methods and Models. Kluwer Academic, Dordrecht.

Arbues, F., Garcia-Valinas, M.A., Martinez-Espineira, R., 2003. Estimation of residential water demand: a state-of-the-art review. Journal of Socio-Economics 32 . 81-102.

Arendt, R., 1999. Growing Greener: Putting Conservation into Local Plans and Ordinances. Island Press, Washington, DC.

Banner, R.E., Baldwin, B.D., Leydsman McGinty, E.I., 2009. Rangeland Resources of Utah, USU Control No. 080300. Utah State University Cooperative Extension, Logan, UT.

Baum, M.C., Dukes, M.D., Miller, G.L., 2005. Analysis of residential irrigation distribution uniformity. Journal of Irrigation and Drainage Engineering 131 (4), 336-341.

Baumann, D.D., Boland, J.J., Hanemann, W.M., 1998. Urban Water Demand Management and Planning. McGraw-Hill, New York.

Bishop, A.B., Hughes, T.C., 1993. A GIS water planning model for urban and agricultural areas. In: Proceedings of the National Conference on Irrigation and Drainage Engineering, ASCE, Park City, UT, pp. 164-171.

Bivand, R.S., Pebesma, E.J., Gomez-Rubio, V., 2008. Applied Spatial Data Analysis with R. Springer Science + Business Media, LLC, New York, NY.

Brown, L.R., 2008. Plan B 3.0: Moblizing to Save Civilization. W.W. Norton \& Company, Inc, New York, NY.

Choudhury, B., Monteith, J., 1986. Implications of stomatal response to saturation deficit for the heat balance of vegetation. Agricultural Meteorology 36, 215-225.

Conway, T.M., Urbani, L., 2007. Variations in municipal urban forestry policies: a case study of Toronto, Canada. Urban Forestry \& Urban Greening 6, 181192.

Costello, L.R., Jones, K.S., 1994. Water Use Classification of Landscape Species: A Guide to the Water Needs of Landscape Plants. University of California Cooperative Extension, San Francisco, CA.

Dwyer, J.F., Schroeder, H.W., Gobster, P.H., 1991. Central hardwood forest resources: a social science perspective. General Technical Report NE 148-USDA Forest Service, Northeastern Forest Expt. Sta.

Dziegielewski, B., Boland, J.J., 1989. Forecasting urban water use: the IWR-MAIN model. Journal of the American Water Resources Association 25 (1), 101109.

Endter-Wada, J., Kurtzman, J., Keenan, S.P., Kjelgren, R.K., Neale, C.M.U., 2008. Situational waste in landscape watering: residential and business water use in an urban Utah community. Journal of the American Water Resources Association 44 (4), 902-920.

Farag, F.A., 2003. Estimating farm and landscape water use at the rural-urban interface using remote sensing and geographic information systems. Ph.D. Dissertation. Utah State University, Logan, Utah.

Farag, F., Neal, C., Kjelgren, R., Endter-Wada, J., in press. Quantifying urban landscape water conservation potential using high resolution remote sensing and GIS. Photogrammetric Engineering and Remote Sensing.

Faraway, J.J., 2005. Linear Models with R. Chapman \& Hall/CRC, New York, NY.

Gleick, P.H., 2000. A look at twenty-first century water resources development. Water International 25 (1), 127-138.

Grove, J.M., Troy, A.R., O’Neil-Dunne, J., Burch, W.R.J., Cadenasso, M.L., Pickett, S.T., 2006. Characterization of households and its implications for vegetation of urban ecosystems. Ecosystems 9, 578-597.

Hanak, E., Davis, M., 2006. Lawns and Water Demand in California. Public Policy Institute of California, San Fransisco, CA.

Heynen, N.C., Lindsey, G., 2003. Correlates of urban forest canopy cover. Public Works Management \& Policy 8 (1), 33-47.

Hope, D., Gries, C., Zhu, W., Fagan, W.F., Redman, C.L., Grimm, N.B., Nelson, A.L., Martin, C.A., Kinzig, A., 2003. Socioeconomics drive urban plan diversity. PNAS 100 (15), 8788-8792.

Huang, Y.J., Akbari, H., Taha, H., 1990. The wind-sheilding and shading effects of trees on residential heating and cooling. ASHRAE 96, 1403-1411.

Hurd St., B., Hiaire, R., White, J., 2006. Residential landscapes, homeowner attitudes and water-wise choices in New Mexico. Hort-Technology 16, 241-246.

Irrigation Association, 2010. Turf and Landscape Irrigation Best Management Practices, Retrieved February 1st, 2011 from: http://www.irrigation. org/uploadedFiles/Resources/BMP_Revised_12-2010.pdf.

Iverson, L.R., Cook, E.A., 2000. Urban forest cover of the Chicago region and its relation to household density and income. Urban Ecosystems 4, 105-124.

Jain, A., Varsheney, A.K., Joshi, U.C., 2001. Short-term water demand forecast modelling at IIT Kanpur using artificial neural networks. Water Resources Management 15, 299-321.

Jensen, J.R., 2005. Introductory Digital Image Processing. Pearson Prentice Hall, Upper Saddle River.
Johnson, C.W., 1988. Planning for avian wildlife in urbanizing areas in American desert/mountain valley enivronments. Landscape and Urban Planning 16 245-252.

JVWCD, 2010. Jordan Valley Water Conservation District "Slow the Flow, Save $\mathrm{H}_{2} \mathrm{O}$ ", Retrieved January 4th, 2010 from: http://www.slowtheflow.org/.

JVWCD, 2011. Jordan Valley Water Conservation District, Water Conservation Goal, Retrieved February 4th, 2011 from: http://www.conservationgardenpark. org/goal.aspx.

Kaplan, R., 1985. Nature at the doorstep: residential satisfaction and the nearby environment. Journal of Architectural Planning Research 2, 115-127.

Kjelgren, R., Montague, T., Beeson, R., 2005. Water use and stomatal behavior of sweetgum (Liquidambar styraciflua $L$.) relative to reference evaporation in three contrasting regions. Acta Horticulturae 664, 353-360.

Kjelgren, R.K., Rupp, L., Kilgren, D., 2000. Water conservation in urban landscapes. HortScience 35 (6), 1037-1040.

Kneebone, W.R., Kopec, D.M., Mancino, C.F., 1992. Water Requirements and Irrigation. ASA-CSSA-SSSA, Madison, WS.

Larson, K.L., Casgrande, D., Harlan, S.L., Yabiku, S.T., 2009. Residents' yard choices and rationales in a desert city: social priorities, ecological imapcts, and decision tradeoffs. Environmental Management 44, 921-937.

Lee, S.-J., Wentz, E.A., Gober, P., 2010. Space-time forecasting using soft geostatistics: a case study in forecasting municipal water demand in Phoenix, Arizona. Stochastic Environmental Research and Risk Assessment 24 (2), $283-$ 295

Lockett, L., Montague, T., McKenney, C., Auld, D., 2002. Assessing public opinion on water conservation and water conserving landscapes in the semiarid southwestern United States. HortTechnology 12, 392-396.

Lohr, V.I., Pearson-Mims, C.H., Tarnai, J., Dillman, D.A., 2004. How residents rate and rank the benefits and problems associated with trees in cities. Journal of Arboriculture 29, 9-17.

Lowry, J.H., Jr., 2010, Spatial analysis of urbanization in the Salt Lake Valley: an urban ecosystem perspective. Ph.D. Dissertation. Utah State University, Logan, Utah.

Maco, S.E., McPherson, E.G., 2002. Assessing canopy cover over streets and sidewalks in street tree populations. Journal of Arboriculture 28 (6), 270 276.

Martin, C.A., Warren, P.S., Kinzig, A.P., 2004. Neighborhood socioeconomic status is a useful predictor of perennial landscape vegetation in residential neighborhoods and embedded small parks of Phoenix, AZ. Landscape and Urban Planning 69, $355-368$.

McPherson, G.E., 1990. Modeling residential landscape water and energy use to evaluate water conservation policies. Landscape Journal 9, 122-134.

Montague, T., Kjelgren, R., Allen, R., Wester, D., 2004. Water loss estimates for five recently transplanted landscape tree species in a semi-arid climate. Journal of Environmental Horticulture 22, 189-196.

McPherson, G.E., 1992. Accounting for benefits and costs of urban greenspace. Landscape and Urban Planning 22, 41-51.

McPherson, G.E., Simpson, J.R., Qingfu, X., Wu, C., 2008. Los Angeles 1-Million Tree Canopy Cover Assessment. USDA, Forest Service, Pacific Southwest Research Station.

Miller, R.W., 1997. Urban Forestry: Planning and Managing Urban Greenspaces. Prentice Hall, Upper Saddle River, NJ.

Msiza, I.S., Nelwamondo, F.V., Marwala, T., 2008. Water demand prediction using artificial neural networks and support vector regression. Journal of Computers $3(11), 1-8$.

NAIP, 2006. National Agriculture Imagery Program, Retrieved June 10th, 2007 from: http://agrc.its.state.ut.us/.

Nowak, D.J., Crane, D.E., 2002. Carbon storage and sequestration by urban trees in the USA. Environmental Pollution 116, 381-389.

Nowak, D.J., Crane, D.E., Stevens, J.C., 2006. Air pollution removal by urban trees and shrubs in the United States. Urban Forestry \& Urban Greening 4, 115-123.

Nowak, D.J., Dwyer, J.F., 2007. In: Kuser, J.E. (Ed.), Understanding Benefits And Costs Of Urban Forests. Spinger, New York.

Pannuk, T.R., White, R.H., Steinke, K., Aitkenhead-Peterson, J.A., Chalmers, D.R. Thomas, J.C., 2010. Landscape coefficients for single- and mixed-species landscapes. HortScience 45 (10), 1529-1533.

Pittenger, D.R., Shaw, D.A., 2007. Review of research on water needs of landscape plants. In: 2007 Symposium on Efficient Water Use in the Urban Landscape New Mexico State University, Las Cruces, NM.

Sachs, R.M., Kretchum, T. Mock, T., 1975. Minimum irrigation requirements. Journal of the American Society for Horticultural Science 100, 499-502.

Salt Lake County, 2010. Demographics, Retrieved July 17th, 2010, from: http://www.upgrade.slco.org/demographics/population.html.

Sanders, R.A., 1984. Some determinants of urban forest structure. Urban Ecology 8, $13-27$.

Schroeder, H.W., Cannon Jr., W.N., 1987. Visual quality of residential streets: both street and yard trees make a difference. Journal of Arboriculture 13, 236-239.

Sepaskhah, A.R., Ahmadi, S.H., 2010. A review on partial root-zone drying irrigation. International Journal of Plant Production 4, 241-258.

SLCo, 1977. Water Supply and Use: Status and Outlook in Salt Lake County, 208 Water Quality Project. Salt Lake County, Salt Lake City, Utah.

Solley, W.B., Merk, C.F., Pierce, R.R., 1988. Estimated Use of Water in the United States in I985, USGS Circular 1004. United States Geological Survey, Denver, CO.

Solley, W.B., Pierce, R.R., Perlman, H.A., 1998. Estimated Use of Water in the United States in 1995, USGS Circular 1200. United States Geological Survey, Denver, CO. 
Sovocool, K.A., Morgan, M., Bennet, D., 2006. An in-depth investigation of xeriscape as a water conservation measure. Journal of American Water Works Association $98,82-93$.

Spinti St., J.E., Hiaire, R., VanLeewen, D., 2004. Balancing landscape preferences and water conservation in a desert environment. HortTechnology 14, 72-77.

St. Hilaire, R., Arnold, M.A., Wilkerson, D.C., Devit, D.A., Hurd, B.A., Lesikar, B.J., Lohr V.I., Martin, C.A., McDonald, G.V., Morris, R.L., Pittenger, D.R., Shaw, D., Zoloske, D.F., 2008. Efficient water use in residential urban landscapes. HortScience 43 (7), 2081-2092.

Troy, A.R., Grove, J.M., O’Neil-Dunne, J.P.M., Pickett, S.T.A., Cadenasso, M.L., 2007. Predicting opportunities for greening and patterns of vegetation on private urban lands. Environmental Management 40, 394-412.

Turner, N., Schulze, E., Gollan, T., 1984. The responses of stomata and leaf gas exchange to vapour pressure deficits and soil water content. Oecologia 63 , 338-342.

UDNR-DWR, 2009. Municipal and Industrial Water Supply and Uses in the Jordan River Basin. Utah Department of Natural Resources, Division of Water Resources, Salt Lake City.
U.S. Census Bureau, 2005. U.S. Census Bureau American FactFinder, Retrieved June 4th, 2010 from: http://factfinder.census.gov/.

Utah Climate Center, 2010. Climate Datasets, Retrieved May 1st, 2010, from: http://climate.usurf.usu.edu/products/data.php.

Vickers, A., 1991. The emerging demand-side era in water management. American Water Works Association 83 (10), 38-43.

Vorosmarty, C.J., Green, P., Salisbury, J., Lammers, R.B., 2000. Global water resources: vulnerability from climate change and population growth. Science 289, 284-288.

Wentz, E.A., Gober, P., 2007. Determinants of small-area water consumption for the city of Phoenix, Arizona. Water Resources Management 21, 1849-1863.

Wong, A.K., 1999. Promoting conservation with Irvine Ranch Water District's ascending block rate structure. In: Owens-Viani, L., Wong, A.K., Gleick, P.H. (Eds.), Promoting Conservation with Irvine Ranch Water District's Ascending Block Rate Structure. Pacific Institute for Studies in Development, Environment and Security, Oakland, CA.

Xiao, Q., McPherson, E.G., Simpson, J.R., Ustin, S.L., 1998. Rainfall interception by Sacramento's urban forest. Journal of Arboriculture 24 (4), 235-244. 